\title{
CODAMIN AND BRASSINOLIDE ON BEAN PLANTS
}

\author{
Paulo R. C. Castro ${ }^{1}$, Maria R. Gonçalves ${ }^{2}$, Stella C. Cato ${ }^{1}$
}

\begin{abstract}
The effects of correctives of aminoacid deficiency, Codamin-BR, Codamin B-Mo, Codamin-150, and the plant regulator Brassinolide, applied on bean plants (Phaseolus vulgaris cv. IAC-Carioca Tybatã) growing in pots, were evaluated. The products were sprayed on leaves three times, 15 , 30 and 45 days after germination (DAG). The analyzed variables were plant height, foliar dry matter, number of pods, pod dry matter, number of grains and grain dry matter. In the first assessment, Brassinolide increased plant height and afterwards this compound and Codamin B-Mo reduced this parameter. Foliar dry matter was increased by Codamin-150 and BR. Codamin-BR promoted increases in the number of grains; Codamin-150 and B-Mo also increased grain dry matter.
\end{abstract}

Key words: growth substances, Phaseolus vulgaris, productivity.

\section{CODAMIN E BRASSINOLIDE EM FEIJOEIRO}

\section{RESUMO}

Os efeitos de corretivos da carência de aminoácidos, Codamin-BR, Codamin B-Mo, Codamin-150 e do regulador vegetal Brassinolide, aplicados em plantas de feijoeiro (Phaseolus vulgaris cv. IAC-Carioca Tybatã) envasadas, foram avaliados. Três aplicações foliares dos produtos foram realizadas aos 15,30 e 45 dias após a germinação (DAG). As

\footnotetext{
${ }^{\prime}$ Departamento de Ciências Biológicas, Esalq - USP, Cx. Postal 09, 13418-900. Piracicaba, SP, Brasil

${ }^{2}$ Curso de Pós-Graduação em Ciências Florestais da Esalq-USP.
} 
variáveis analisadas foram a altura das plantas, a massa de matéria seca das folhas, o número de vagens, a massa de matéria seca das vagens, o número de grãos e a massa de matéria seca dos grãos. Na primeira avaliação (33 DAG), o regulador vegetal Brassinolide aumentou a altura das plantas e, posteriormente, Brassinolide e Codamin B-Mo reduziram este parâmetro. A massa de matéria seca das folhas foi incrementada por Codamin-150 e BR. Codamin-BR promoveu aumentos no número de grãos; este produto, Codamin-150 e B-Mo também aumentaram a massa de matéria seca de grãos.

Palavras-chave: substâncias de crescimento, Phaseolus vulgaris, produtividade.

\section{INTRODUCTION}

Researchers and producers of plant growth substances have been trying to develop products that effectively increase bean yield. Therefore, several different bioregulators and biostimulants have been checked. The wide utilization of aminoacids and the demand for micronutrients required by plants have led us to believe that the application of such products may promote development and productivity. Codamin products are corrective of mineral salts deficiency containing aminoacids and, when associated to micronutrients, has being able to provide increases in harvest quantity and quality.

A drop of a solution containing labeled aminoacids on soybean leaves enabled absorption and translocation, at different speed and directions, of several aminoacids inside the plant. Another study, showed that aminoacids moved from a solution through the cutting edges of wheat stem to the small cobs. And when a Rheum sp. leaf was covered with a chamber containing ${ }^{14} \mathrm{CO}_{2}$ the adjacent nervures did not show only labeled sugars, but also organic acids and ${ }^{14} \mathrm{C}$ - labeled aminoacids (Kursanov, 
1961). A drop of a solution containing labeled aminoacids was placed on a peciole cut from soybean primary leaf and several aminoacids were transported inside the plant at different speed and directions (Nelson \& Gorham, 1959a). Absorption rates of labeled aminoacids through the peciole cut from soybean primary leaf varied from 1.0 to $1.5 \mu \mathrm{L}$ per minute, determining, after 1 to 5 minutes, the distribution of ${ }^{14} \mathrm{C}$ in the plant (Nelson \& Gorham 1959b). Aminoacids can be transported through the cell plasmatic membrane by means of transport like simport, penetrating in the cell in parallel to the movement of $\mathrm{H}^{+}$(Taiz \& Zeiger, 2004).

In the group of new hormones, brassinosteroids have an essential role as plant and animal hormones (Castro \& Vieira, 2001; Geuns, 1978). Brassinolide is the most bioactive form of the plant growth promoters in the brassinosteroid group. Because of its low concentration its identification was very difficult. The observation of dwarf mutant phenotype behavior from Arabidopsis, after application of brassinosteroids, was the main reason for the acceptance of this group as hormones (Grove et al., 1979; Mandava, 1988). Brassinosteroids have been reported as having pleiotropic effects, being associated to increases in metabolic processes related to photosynthesis, synthesis of nucleic acids and proteins (Krizek \& Mandava, 1983). They act on proton pumping, membrane polarization (Cerana et al., 1983), in photosynthesis (Braun \& Wild, 1984), response to stresses, especially thermo tolerance (Wilen et al., 1995), and on senescence delay (Mandava, 1988). In legumes, Brassinolide can cause increase in nitrogen fixation for affecting nodulation and nitrate activity (Vardhini \& Rao, 1999).

The objective of this work was to evaluate the effects of Codamin products and Brassinolide on bean plant development and yield. 


\section{MATERIAL AND METHODS}

The experiment was carried out in the experimental field of the Department of Biological Sciences at ESALQ, USP, in Piracicaba, São Paulo state. Bean seeds (Phaseolus vulgaris L. cv. IAC - Carioca Tybatã) were sown in pots, on August $13^{\text {th }}, 2002$. The plants germinated on August 20th, 2002. Two plants were left per pot after thinning. The experiment consisted of five treatments: Codamin-BR $250 \mathrm{ml} \mathrm{ha}^{-1}\left(1 \mathrm{ml} \mathrm{L}^{-1}\right)$; Codamin$1501.25 \mathrm{Lha}^{-1}\left(2.5 \mathrm{ml} \mathrm{L}^{-1}\right)$; Codamin B-Mo $1.25 \mathrm{~L} \mathrm{ha}^{-1}\left(2.5 \mathrm{ml} \mathrm{L}^{-1}\right)$ and Brassinolide $0.005 \%\left(0.3 \mathrm{ml} \mathrm{L}^{-1}\right)$. All treatments were sprayed on leaves 15 , 30 and 45 days after germination (DAG). Control plants were sprayed with water. Plant height measurements were carried out at 33, 44, 51 and 58 DAG. Foliar dry matter, number of pods and grains, pod and grain dry matter were evaluated at harvest. The experimental design was completely randomized with five treatments and eight replications and each plot was represented by a pot containing two plants. The obtained data were submitted to Duncan's test at $5 \%$ of probability and regression equations were established.

\section{RESULTS AND DISCUSSION}

Brassinolide promoted an increase in plant height on the $37^{\text {th }}$ and $44^{\text {th }}$ DAG. On the $58^{\text {th }}$ DAG Brassinolide and Codamin B-Mo reduced this parameter (Figure 1). Grove et al. (1979), showed that Brassinolide promotes elongation of second and third internodes in bean plant.

Codamin-150 and Codamin-BR increased foliar dry matter. The number of pods and pod dry matter decreased under the effect of Codamin150, Brassinolide and Codamin B-Mo. Codamin-BR increased the number of grains. Foliar application of Codamin-BR, Codamin-150 and Codamin B-Mo increased the grain dry matter, while Brassinolide decreased this variable (Table 1). These results were compatible with the statement of 
Coda (2000), that aminoacids and micronutrients can increase the plant vigor providing larger harvests.

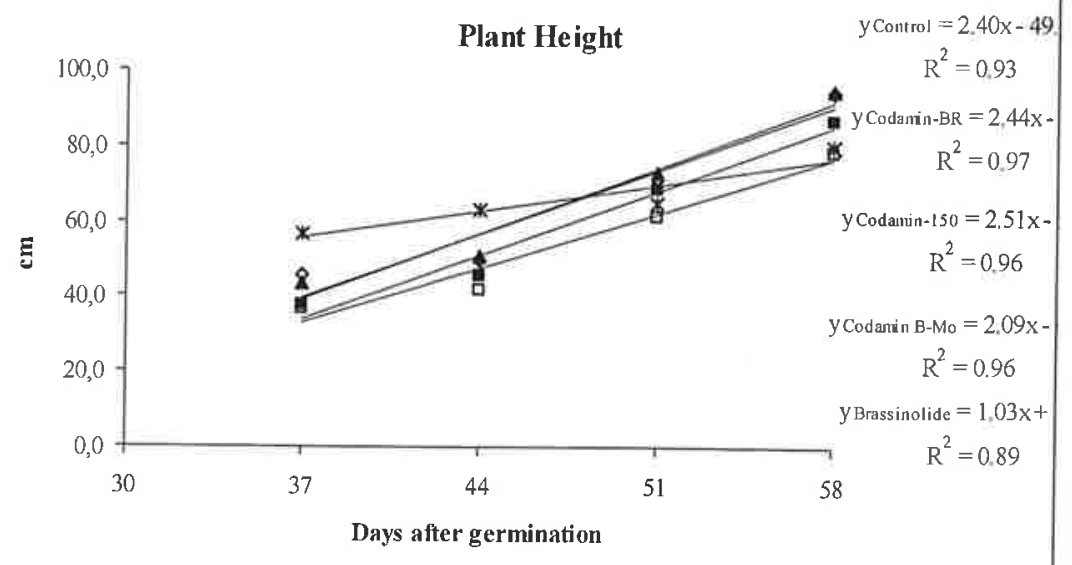

- Control $\boldsymbol{~}$ Codamin-BR $\wedge$ Codamin-150 a Codamin B-Mo $*$ Brassinolide

Figure 1. Bean plant height determined on the $37^{\text {th }}, 44^{\text {th }}, 51^{\text {st }}$ and $58^{\text {th }}$ days after germination treated with Codamin products and Brassinolide, compared to the control.

Table 1. Foliar dry matter, number of pods and grains, pod and grain dry matter of bean plants sprayed with three Codamin products and Brassinolide.

\begin{tabular}{|c|c|c|c|c|c|}
\hline Treatments & $\begin{array}{c}\text { Foliar Dry } \\
\text { Matter } \\
\text { (g plant }^{-1)}\end{array}$ & $\begin{array}{c}\text { Number of } \\
\text { Pods }\end{array}$ & $\begin{array}{c}\text { Pod Dry } \\
\text { Matter (g } \\
\text { plant }^{-1} \text { ) }\end{array}$ & $\begin{array}{c}\text { Number of } \\
\text { Grains }\end{array}$ & $\begin{array}{c}\text { Grain Dry } \\
\text { Matter } \\
\text { (g plant }^{-1} \text { ) }\end{array}$ \\
\hline Control & $49.4 b c$ & $37 a$ & $32.5 \mathrm{a}$ & $94.0 \mathrm{~b}$ & $10.9 \mathrm{~d}$ \\
\hline Codamin-BR & $56.1 \mathrm{a}$ & $36 \mathrm{a}$ & $30.8 \mathrm{ab}$ & $138.0 \mathrm{a}$ & $15.0 \mathrm{a}$ \\
\hline Codamin- 150 & $56.8 \mathrm{a}$ & $21 \mathrm{c}$ & $28.2 \mathrm{~b}$ & $92.7 \mathrm{~b}$ & $11.3 \mathrm{c}$ \\
\hline Codamin B-Mo & $53.9 \mathrm{ab}$ & $27 \mathrm{~b}$ & $21.7 \mathrm{c}$ & $90.7 b$ & $12.0 \mathrm{~b}$ \\
\hline Brassinolide & $45.8 \mathrm{c}$ & $21 \mathrm{c}$ & $24.8 \mathrm{c}$ & $92.0 \mathrm{~b}$ & $10.6 \mathrm{e}$ \\
\hline F(Treat) & $4.7^{* \star}$ & $33.0^{* \frac{\pi}{x}}$ & $15.7 * *$ & $322.2^{\star \star}$ & $392.4 * *$ \\
\hline V.C. $(\%)$ & 11.7 & 13.4 & 11.4 & 3.2 & 2.1 \\
\hline
\end{tabular}

Means followed by the same letters in the columns do not differ among them by Duncan's test at $5 \%$ of significance.

** significative at the level of $1 \%$ of probability 


\section{CONCLUSION}

Codamin-150 and Codamin-BR promoted increases in foliar dry matter of bean plants. Higher number of grains was obtained with the foliar application of Codamin-BR. Codamin-BR, Codamin-150 and Codamin BMo increased the dry matter of harvested grains.

\section{BIBLIOGRAPHY}

BRAUN, P.; A. WILD. 1984. The influence of brassinosteroid on growth and parameters of photosynthesis of wheat and mustard plants. Journal of Plant Physiology, 116: 189-196.

CASTRO, P.R.C.; E.L. VIEIRA. 2001. Aplicações de Reguladores Vegetais na Agricultura Tropical. Livr. Ed. Agropecuária, Guaíba, $132 \mathrm{p}$.

CODA. Nutrição Vegetal. 2000. Almacelles: Compañia de Agroquímicos, 11p. (Catálogo Geral).

CERANA, R; A. BONETTI; M.T. MARRE; G. ROMANI; P. LADO; E. MARRE. 1983. Effects of brassinosteroid on growth and eletrogenic proton extrusion in Azuki bean epicotyls. Physiologia Plantarum, 59: 23-27.

GEUNS, J.M.C. 1978. Plant steroid hormones. Biochemical Society Transactions, 11: 543-548.

GROVE, M.D.; G. F. SPENCER; W.K. ROHWEDDER; N.A. MANDAVA; J. F. WORLEY; G.L. STEFFENS; J. L. FLIPPENANDERSON; C. COOK. 1979. Brassinolide, a plant growth promoting steroid isolated from Brassica napus pollen. Nature, 281: 216-217. KRIZEK, D.T.; N.B. MANDAVA, 1983. Influence of spectral quality on the growth-response of intact bean plants of brassinosteroid, a growth 
promoting steroidal lactone. 2. Chlorophyll content and partitioning of assimilate. Physiologia Plantarum, 57: 324-329.

KURSANOV, A L. 1961. The transport of organic substances in plants. Endeavour, 20: 19-25.

MANDAVA, N.B. 1988. Plant growth promoting brassinosteroids. Annual Review of Plant Physiology and Plant Molecular Biology, 39: 23-52. NELSON, C.D.; P.R. GORHAM, 1959a.Translocation of ${ }^{14} \mathrm{C}$ - labeled amino acids and amides in the stems of young soybean plants. Canadian Journal of Botany, 37: 431-438.

NELSON, C.D.; P.R. GORHAM, 1959b. Physiological control of the distribution of translocated amino acids and amides in young soybean plants. Canadian Journal of Botany, 37: 439-447.

TAIZ, L.; E. ZEIGER, 2004. Fisiologia Vegetal. Porto Alegre: Artmed, $719 \mathrm{p}$.

VARDHINI, B.V.; S.S.R. RAO, 1999. Effect of brassinosteroids on nodulation and nitrogenase activity in groundnut (Arachis hypogaea L.). Plant Growth Regulation, 28: 165-167.

WILEN, R.W.; J. M. WILSOS; E. M. MEYEROWITZ. 1995. A possible role for kinase associated protein phosphatase in thermotolerance of bromegrass (Bromus inemis) cell cultures. Physiologia Plantarum, 95: 185-192. 